\title{
Characterizing the complexity of the fleet dynamics for an effective fisheries management: The case of the Cíes Islands (NW Spain)
}

\author{
Rosana Ouréns ${ }^{1}$, Giulia Cambiè ${ }^{2}$, Juan Freire ${ }^{3}$ \\ ${ }^{1}$ Hopkins Marine Station, Stanford University, 120 Ocean View Blvd., Pacific Grove, CA 93950, USA. \\ E-mail: rosanaoc@gmail.com \\ ${ }^{2}$ School of Ocean Sciences, Bangor University, Menai Bridge, Anglesey, LL59 5AB, UK. \\ ${ }^{3}$ TEAMLABS, C. de la Colegiata 9, 28009 Madrid, Spain.
}

\begin{abstract}
Summary: We analysed the fishing fleet dynamics in the Cíes Islands, located in a National Land-Marine Park of Galicia. By interviewing fishers we identified the fleet fishing in the study area and obtained temporal data on effort and catch. Then we performed multivariate analyses of the catch profiles to identify the fishing strategies and their temporal dynamics. Our results highlight the complexity of the fishery system, composed of 565 boats that used 19 fishing gears and 33 strategies in an area of $26.6 \mathrm{~km}^{2}$. Octopus and velvet crab pots, gillnets targeting hake, trammel nets targeting European spider crab or ballan wrasse, clam rakes, and hand harvesting of gooseneck barnacles and razor shells are the strategies most used. In addition, most of the boats are generalists and use up to seven different fishing strategies throughout the year. This flexibility of the fleet to change the target species generates a wide diversity of annual fishing patterns that increases the complexity of the fisheries and the difficulty of managing them. The implementation of data collection programmes that include fleet dynamics and spatial data are key factors for developing effective management regulations consistent with the complexity of the system.
\end{abstract}

Keywords: small-scale fisheries; fishing strategies; fleet dynamics; fishing effort; Galicia.

Caracterizando la complejidad de la dinámica de la flota para una gestión pesquera efectiva: el caso de las Islas Cíes (NO España)

Resumen: Este estudio analiza la dinámica de la flota pesquera en las Islas Cíes, localizadas en el Parque Nacional marítimoterrestre de Galicia. Por medio de entrevistas a pescadores hemos identificado la flota en la zona de estudio y hemos obtenido datos temporales de esfuerzo y capturas. A continuación hemos llevado a cabo un análisis multivariante de los perfiles de capturas para identificar las estrategias de pesca y su dinámica temporal. Nuestros resultados resaltan la complejidad del sistema pesquero, compuesto por 565 barcos que usan 19 artes y 33 estrategias de pesca diferentes en un área de $26.6 \mathrm{~km}^{2}$. Las estrategias de pesca más usadas son nasas de pulpo y nécora, arte de enmalle fijo dirigido a la captura de pescadilla, trasmallos dirigidos a la pesca de centolla y maragota, rastros para almeja, y recolección manual de percebe y navaja. Cabe decir también que la mayoría de los barcos son generalistas y utilizan hasta 7 estrategias diferentes a lo largo del año. Esta flexibilidad de la flota para cambiar su especie objetivo genera una amplia diversidad de patrones anuales de pesca que todavía incrementan más la complejidad del sistema y la dificultad para gestionarlo. La implementación de programas de recogida de datos que incluyan la dinámica de la flota y datos espaciales son clave para desarrollar unas regulaciones de gestión efectivas y consistentes con la complejidad del sistema.

Palabras clave: pesquerías de pequeña escala; estrategias de pesca; dinámica de flota; esfuerzo pesquero; Galicia.

Citation/Como citar este artículo: Ouréns R., Cambiè G., Freire J. 2015. Characterizing the complexity of the fleet dynamics for an effective fisheries management: The case of the Cíes Islands (NW Spain). Sci. Mar. 79(4): 453-464. doi: http:// dx.doi.org/10.3989/scimar.04228.08A

Editor: P. Martín.

Received: February 12, 2015. Accepted: July 6, 2015. Published: October 8, 2015.

Copyright: () 2015 CSIC. This is an open-access article distributed under the Creative Commons Attribution-Non Commercial Lisence (by-nc) Spain 3.0. 


\section{INTRODUCTION}

The fraction of assessed stocks fished within biologically sustainable levels decreased by almost $20 \%$ from 1974 to 2011 (FAO 2014), and the situation seems to be even worse for unassessed fisheries (Costello et al. 2012). With the aim of reverting this trend, the scientific community and international organizations such as FAO are making great efforts to understand the functioning of marine ecosystems and the reasons for the failure of fisheries management.

One of the most innovative and novel approaches that is being currently applied is the ecosystem approach to fisheries (EAF) (FAO 2003). This approach differs from the conventional single-species approach in that it analyses the fishing system as a whole, taking into account the functioning of the ecological and human components that constitute the fishery system and their interactions at different spatial and temporal scales (De Young et al. 2008, Levin et al. 2009, Jennings and Rice 2011). The successful implementation of the EAF therefore requires a holistic vision, and consequently research needs have emerged in both social and natural disciplines (Leslie and McLeod 2011).

Understanding the fleet behaviour and fishing patterns in space and time is one of the essential requirements for implementing the EAF for two reasons. First, most small-scale fisheries are complex systems that encompass different fleets exploiting a huge variety of species. Depending on the context in which they work, boats can easily change their target species in order to maximize the economic benefits and use different fishing strategies or mètiers (combinations of fishing area, target species, season and fishing gear; see Tzanatos et al. 2006). Ignoring this variability can generate a simplistic and biased vision of the fishing activity, which may lead to misinterpretation of how fishers allocate the fishing effort in space and time and of the impact caused by the fishing effort on the ecosystem (Salas and Gaertner 2004, Forcada et al. 2010, Maynou et al. 2011, Martín et al. 2014). Second, fishers' behaviour is one of the main sources of uncertainty associated with the fishing systems, so ignoring the patterns of human interventions could undermine the effectiveness of management strategies (FAO 2003, Fulton et al. 2011, Maravelias et al. 2014).

Several studies also mention the need to understand the spatial and temporal heterogeneity of the marine ecosystems and their associated human communities, as well as the multiple scales on which they operate (Crowder and Norse 2008, Leslie and McLeod 2011). However, most data collection systems still ignore the spatial component, making it difficult to establish regulation measures that take into account the specific characteristics of each fishing area (Orensanz and Jamieson 1998, Booth 2000). Even worse, in some cases the lack of spatial information has generated mismatches between the governance scale and the spatial organization of fishing systems, leading to unexpected outcomes of the management measures (Folke et al. 2007, Ouréns et al. 2015). An evident example can be found in Galicia (NW Spain), where the catch statistics include the first sale market as a spatial reference, but not the fishing ground (Pita et al. 2008, Villasante 2010). The missing spatially explicit information leads to a lack of knowledge on the fishing pressure exerted on resources and on the environment (i.e. non-target communities and habitats), even in areas of special ecological value such as marine reserves or National Parks.

This article contributes to the EAF by providing information on fishing fleet dynamics, fishing strategies and fishing effort around the Cíes Islands, a small archipelago included in the National Land-Marine Park of the Atlantic Islands of Galicia. Despite the establishment of the National Marine Park in 2002, data currently available only focus on the economic performance of the fleet (Cambiè et al. 2012) and no information on the fishing strategies and their spatial-temporal patterns has been provided. With a cost-effective methodology based on interviewing fishers, we provide essential information for a better understanding of the complexity of the fishing system in the Cíes Islands. Although we aware that the implementation of data collection programmes that integrate fleet dynamics information in a real-time adaptive system is desirable, our methodology is useful for establishing a solid basis of knowledge for designing effective management strategies.

\section{METHODOLOGY}

\section{Study area and current fishing management policies}

Galicia (NW Spain) is one of Europe's regions with the highest socio-economic dependence on fishing, due to its high production and employment rate and its relationship with other local economic sectors (Losada 2000, Varela Lafuente and Iglesias Malvido 2000). Its large fleet size (4497 vessels in 2015) and their high landings (187177 $t$ with a value of EUR 432 million in 2014; http://www.pescadegalicia.com) make Galicia a leader in the fishing industry at the national level, representing around $50 \%$ of Spanish landings in volume and value, and nearly $40 \%$ of the number of direct jobs (Villasante 2010).

Our study was carried out in the inner coastal waters of Galicia, where fishing resources are managed by the Galician government (although always following the rules established at broader scales, such as total allowable catches imposed by the European Union for many target species of purse seine). Boats have a fishing licence in which the authorized fishing gears are specified. Boats are allowed to use a maximum of five different fishing gears, although they can only use one per day, and purse seiners are only allowed to fish using seine nets. Most fishing resources are exploited according to a centralized management model, whose main regulations are aimed at restricting the fishing effort (establishing seasonal closures, limiting the gear size or the fishing daily hours) and the minimum commercial size.

In 1992 Galicia established a co-management system for shellfish based on the assignment of territorial use rights (TURFs) to local fishers' organizations according to the historical spatial pattern of fleet activity, 
and on limiting fisheries access to a given number of boats (and persons if the resources are collected from the shore) belonging to the local fishers' organizations co-managing each particular stretch of coast. In addition, fishers' organizations must propose additional regulations for their territories by drawing up annual exploitation plans (including fisher/boat daily quotas, total number of fishing days, marketing strategies, etc.), which have to be finally supervised and accepted by the regional government (Molares and Freire 2003, Macho et al. 2013). The new co-management system is only applied to some benthic fisheries that could be classified as S-fisheries (small-scale, spatially structured fisheries targeting sedentary stocks, sensu Orensanz et al. 2005). Most of these fisheries are mono-specific since the resources are hand-harvested (e.g. gooseneck barnacles, sea urchins, razor clams, abalone) and therefore they are managed at species level. The clam fisheries, however, are managed per gear since they include different species. We will refer to those resources managed through TURFs as S-fisheries.

Our study took place in the Cíes Islands, located in the outer area of the Ría de Vigo (Fig. 1). The archipelago is characterized by high species richness as well as high levels of fisheries production, due to the local upwelling that promotes phytoplankton blooms (ÁlvarezSalgado et al. 2000, Rodil et al. 2009). The Cíes Islands belong to the National Park Illas Atlánticas de Galicia established in 2002, and they are a strategic fishing ground for many Galician fleets (Cambiè et al. 2012). Though fishing ground of the Cíes Islands is protected, it is not currently subject to a special regulation. Because the official data do not include the fishing ground (only the area of first sale) and there is no monitoring mechanism within the National Park, the fishing pressure exerted on the resources in this area is unknown and effective regulations cannot be implemented.

\section{Describing the fleet of the Cíes Islands}

The fieldwork started in February 2009 with the interview of a random sample of fishers about fishing gears that they used in 2008 and ones that were used in the Cíes Islands for at least one month. Fishers were initially approached in Cangas because it is the closest port to the Cíes Islands, and then in the ports located to the north and south, until no more boats working in the Cíes Islands could be found. We stopped the surveys in the ports of Cambados (north of Cangas) and A Guarda (south of Cangas), covering around $195 \mathrm{~km}$ of coastline. Because the landing time depends on the type of fishing gear, we visited the ports at different times.

We finished the surveys in each port when we obtained a confidence interval of $95 \%$ on the percentage of vessels fishing in the Cíes Islands per gear. The number of surveys required $(n=424)$ was estimated by applying the central limit theorem, whereby a binomial distribution (fishing in the Cíes Islands or not) can be approximated by a normal distribution for large sample sizes.

The fleet size operating in the Cíes Islands was estimated by applying the percentage of respondents who were fishing in the study area to the total number

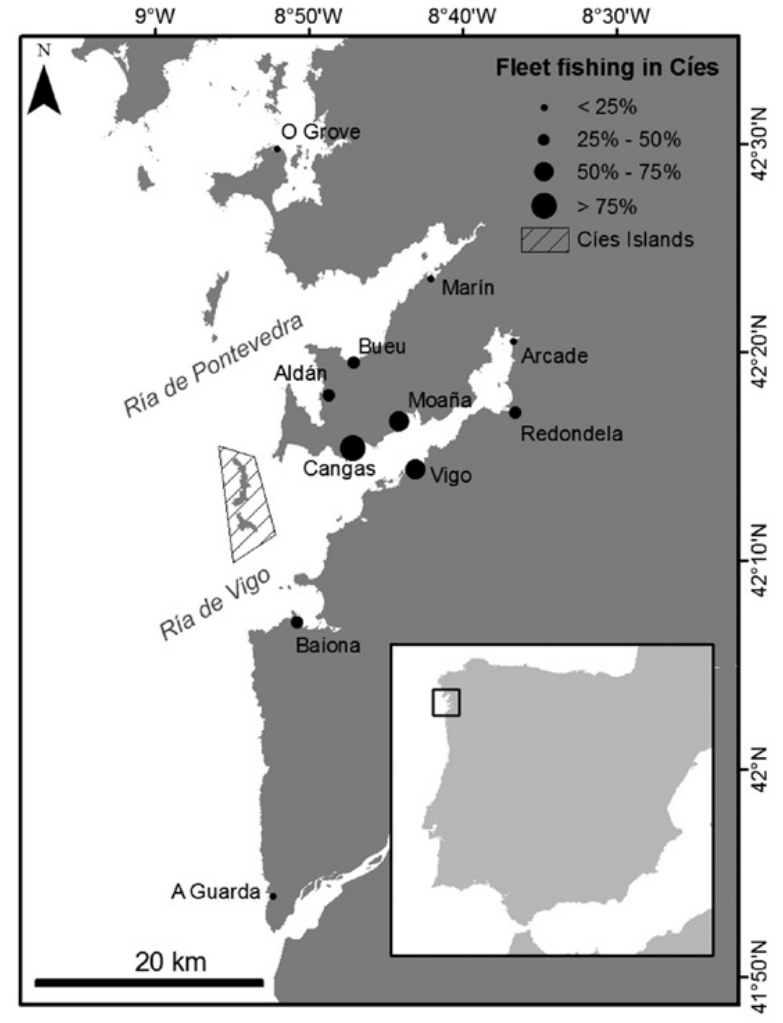

Fig. 1. - Study area with the location of the base ports of the fleet fishing in the Cíes Islands. The percentage of the fleet of each port that fishes in the Cíes Islands is indicated.

of fishing licences. The total number of licences per fishing gear and port, as well as the technical characteristics of the vessels (length, tonnage and engine), is public information that is available on the web platform "Pesca de Galicia" (http://www.pescadegalicia. com/2, under the regional government of Galicia.

Then we described the fleets according to their area of origin and the fishing gears that they used. The fleet was also divided into three segments according to the Scientific, Technical and Economic Committee for Fisheries of the European Commission and its data collection framework (DCF) used until 2010: artisanal (vessels of less than $12 \mathrm{~m}$ length using active and passive gears), polyvalent (boats of between 12 and $24 \mathrm{~m}$ length using passive gears), and purse seiners (boats between 12 and $24 \mathrm{~m}$ length using seine nets).

\section{Identifying fishing strategies}

When we had estimated the fleet size of the Cíes Islands, we interviewed $20 \%$ of the boats from different ports that fished in the Cíes Islands with each gear. Informants $(n=96)$ were interviewed individually on the dimensions of the gear (see below, "Quantifying the fishing effort" section), the season in which the gears were used, and monthly catch weights by species obtained with each of them.

Catch data were analysed separately per gear in order to identify the different fishing strategies performed with each one. The analyses were performed 
for gears with a representation higher than $3 \%$ in the Cíes Islands, and therefore we had information from at least five interviews per fishing gear. All fishing operations carried out with a mono-specific gear were considered part of the same fishing strategy. Regarding multi-species gears, the strategies were identified by applying multivariate analysis techniques on the basis of the catch composition (Pelletier and Ferraris 2000, Silva et al. 2002, Maynou et al. 2011). Thus, we built a matrix in which the variables were catch species and the cases were monthly landings per boat. Absolute catches were transformed to relative catches for each vessel separately, by dividing monthly catch per species by the overall annual catch of each vessel. This transformation allowed us to homogenize the catch units, removing the differences due mainly to the variation in the fishing effort.

Then, we carried out a hierarchical cluster analysis using Chord distances as a dissimilarity index and the minimum variance criterion of Ward (1963) as a clustering algorithm. We used the Chord distance because it is an asymmetric index, so the distances are estimated without taking into account the double-zeros (i.e. the absence of a given species from two fishing strategies cannot readily be counted as an indication of resemblance between these fishing strategies). We determined the optimal number of clusters in each analysis based on graphical methods (plotting the fusion level values of the dendrograms in order to choose the minimum number of clusters that explain the most variance) and statistical methods (silhouette coefficients and Mantel correlation between the distance matrix and binary matrices computed from the dendrogram cut at various levels). The results were similar with both methods, so we used our experience in the Galician fisheries to decide the final number of clusters. As a general rule, we observed that the optimal cut-off value was often around 5. Finally, some fishers validated the catch profiles that we identified in order to check the data had been correctly grouped and the clusters actually corresponded with different fishing strategies.

\section{Identifying the fleet dynamics}

We described the fleet dynamics through the seasonal variability in the use of the fishing strategies. In addition, we studied the combination of strategies most frequently used by identifying groups of vessels with similar fishing activities throughout the year. Following the methodology proposed by Ulrich and Andersen (2004), we applied the same multivariate procedure as used for the identification of landings profiles. In this case, the data matrix was built with vessels as cases and the percentage of days using each strategy as variables. This analysis allowed us to identify the main and secondary fisheries for each fleet.

\section{Quantifying the fishing effort}

Nominal fishing effort depends on the duration of the fishing activity and the fishing capacity (World Bank 2009). The latter factor is the ability of a ves- sel to catch fish, and it can be measured through the characteristics of the fleet (number of vessels, engine power, vessel size, etc.) and the type and amount of fishing gear (Pascoe et al. 2003).

We estimated the fishing effort $\left(\mathrm{FE}_{1}\right)$ as the product of the gross tonnage (GT) and the average number of fishing days in the Cíes Islands for each fleet segment (artisanal, polyvalent and purse seiners):

$$
\mathrm{FE}_{1}=\mathrm{N} \sum_{\mathrm{i}=1}^{\mathrm{n}} \mathrm{GT} \cdot \text { No Days }
$$

where $\mathrm{i}=1, \ldots, \mathrm{n}$ interviewed vessels, and $\mathrm{N}$ is the estimated number of boats fishing in the Cíes Islands.

The fishing effort estimated by means of this equation allows to interpret the level of fishing pressure exerted over the fishing area, and it is often used to regulate fishing capacity in order to minimize overfishing. However, this measure does not reflect the level of activity carried out at a fishery scale. In this regard, the fishing effort estimated by means of gear characteristics is easily related to fishing mortality, thus being more applicable to estimating catch and monitoring stock trends (FAO 1999, McCluskey and Lewison 2008). For this reason, we also quantified the fishing effort associated with each fishing strategy using the dimensions of the gears as indicators of capacity: number of hooks (for lines and longlines), number of pots (for trap gears), length of the wing net (for trawls), length of net (for gillnets and trammel nets), or number of harvesters (divers, crew, rakes or dredges for Sfisheries), as appropriate.

This latter effort indicator $\left(\mathrm{FE}_{2}\right)$ was only estimated for the strategies used by artisanal boats, which share similar technical characteristics. Purse seiners, in addition to their different technical characteristics, are often equipped with advanced technology to detect and attract fish, which clearly increases the fishing efficiency of the gear. Since we did not have sufficient information to include these factors in the indicator, the effort exerted by purse seiners was only estimated through $\mathrm{FE}_{1}$. The polyvalent segment has very little representation in the study area $(2.5 \%$ of the fleet in Cíes), so it was also removed from this estimation. Comparisons of the fishing effort associated with the strategies within each type of gear were performed by means of a one-way analysis of variance (ANOVA). The fishing effort was log transformed to correct the heteroscedasticity of the data.

All analyses were carried out with the R 3.1.1. programming language (R Core Team 2014).

\section{RESULTS}

\section{Fleet composition}

A total of 565 boats (515 artisanal, 15 polyvalent and 35 purse seiners) fish around the Cíes Islands for at least one month a year. The fleet comes from 11 ports of southern Galicia (Fig. 1), though the majority of boats come from the nearest ports located in the outer zone of the Rías de Vigo and Pontevedra. Because of their distance, Marín and O Grove ports are only represented 
Table 1. - Fishing gears in the Cíes Islands in 2008 and their importance in terms of the number (and 95\% confidence intervals) and percentage of boats using them. Asterisks show gears used for S-fisheries, which are managed by means of territorial use rights in Galicia.

\begin{tabular}{|c|c|c|c|c|c|c|c|c|c|}
\hline \multirow{3}{*}{$\begin{array}{l}\text { Local name } \\
\text { Betas }\end{array}$} & \multicolumn{2}{|c|}{ Gear } & \multirow{3}{*}{$\begin{array}{c}\text { No } \\
\text { licences }\end{array}$} & \multirow{3}{*}{$\begin{array}{c}\begin{array}{c}\text { No } \\
\text { surveys }\end{array} \\
136\end{array}$} & \multicolumn{4}{|c|}{ Fleet in Cíes Islands } & \multirow{3}{*}{$\begin{array}{c}\% \text { fleet in } \\
\text { relation to the } \\
\text { total of Cíes }\end{array}$} \\
\hline & Code & English name & & & \multirow{2}{*}{$\begin{array}{c}\% \\
25.7\end{array}$} & \multirow{2}{*}{$\begin{array}{c}\text { No vessels } \\
69.7\end{array}$} & \multicolumn{2}{|c|}{ CI $95 \%$} & \\
\hline & $\mathrm{BE}$ & Set gillnets & & & & & 57.5 & 85.5 & \\
\hline Boliche & $\mathrm{BO}$ & Small-mesh trawls & 87 & 40 & 30.0 & 26.1 & 18.8 & 36.3 & 3.3 \\
\hline Bou de man & $\mathrm{BM}$ & Large-mesh trawls & 40 & 17 & 29.4 & 11.8 & 7.3 & 19.1 & 1.5 \\
\hline Cerco & $\mathrm{CE}$ & Purse seines & 49 & 25 & 72.0 & 35.3 & 28.2 & 39.6 & 4.4 \\
\hline Endeño remolcado* & $\mathrm{EN}$ & Mechanized clam rakes & 16 & 8 & 62.5 & 10.0 & 6.7 & 12.1 & 1.3 \\
\hline Liña & LI & Handlines & 263 & 79 & 7.6 & 20.0 & 11.1 & 39.0 & 2.5 \\
\hline Miños & MI & Large-mesh trammel nets & 300 & 148 & 30.4 & 91.2 & 76.9 & 108.4 & 11.4 \\
\hline Nasa camarón & $\mathrm{NC}$ & Pots targeting shrimps & 275 & 98 & 5.1 & 14.0 & 7.7 & 29.4 & 1.8 \\
\hline Nasa fanequeira & NF & Pots targeting pouts & 8 & 5 & 40.0 & 3.2 & 3.2 & 3.2 & 0.4 \\
\hline Nasa nécora & NN & Pots targeting velvet crab & 449 & 205 & 20.5 & 92.0 & 76.0 & 112.7 & 11.5 \\
\hline Nasa polbo & NP & Pots targeting octopus & 400 & 191 & 26.7 & 106.8 & 90.4 & 126.7 & 13.4 \\
\hline Navalla* & NV & Razor clam harvesting & 17 & 13 & 100.0 & 17.0 & 14.3 & 17.0 & 2.1 \\
\hline Ourizo* & $\mathrm{OU}$ & Sea urchin harvesting & 7 & 7 & 71.4 & 5.0 & 0.0 & 0.0 & 0.6 \\
\hline Palangrillo & PA & Set and bottom longlines & 153 & 84 & 19.0 & 29.1 & 22.5 & 39.8 & 3.7 \\
\hline Percebe* & $\mathrm{PE}$ & Goose barnacle harvesting & 34 & 21 & 100.0 & 34.0 & 29.2 & 34.0 & 4.3 \\
\hline Racú & RA & Artisanal purse seines & 5 & 5 & 80.0 & 4.0 & 4.0 & 4.0 & 0.5 \\
\hline Rastro bivalvos* & $\mathrm{RB}$ & Manual clam rakes & 341 & 139 & 41.0 & 139.8 & 119.4 & 161.9 & 17.5 \\
\hline Trasmallos & $\mathrm{TR}$ & Small-mesh trammel nets & 347 & 139 & 17.3 & 59.9 & 45.8 & 79.9 & 7.5 \\
\hline Xeito & $\mathrm{XE}$ & Drifting gillnets & 140 & 58 & 22.4 & 31.4 & 22.3 & 45.1 & 3.9 \\
\hline TOTAL & & & 3202 & 1418 & & 800.4 & 641.3 & 993.8 & 100.0 \\
\hline
\end{tabular}
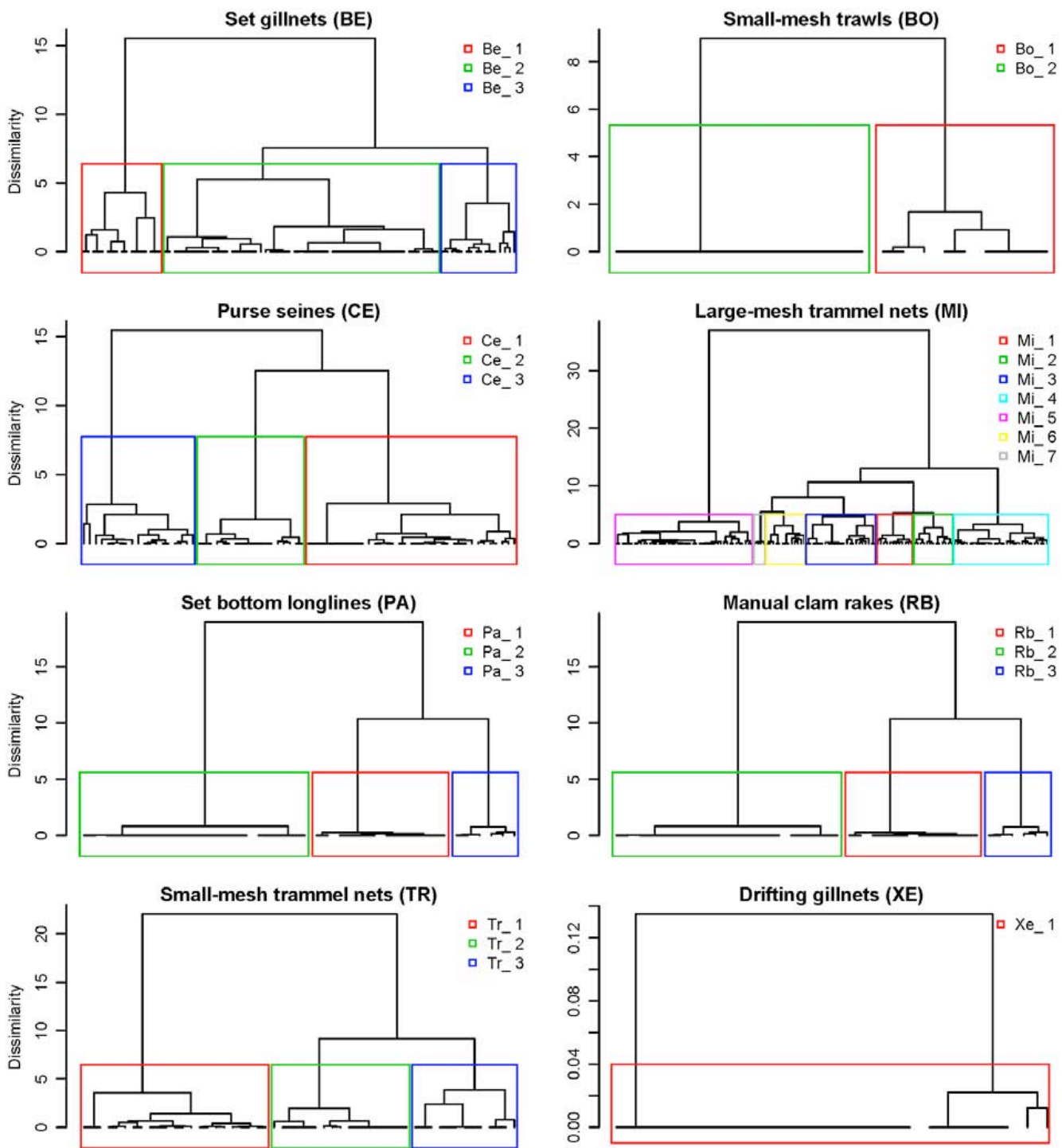

Fig. 2. - Dendrograms from hierarchical clustering using species catches data. Groups identified as distinct fishing strategies within fishing gear are shown. Note that the scale in the Y-axis changes between plots. 
Table 2. - Catch profiles of the fishing strategies used in the Cíes Islands. The percentage of the catches is shown in brackets. The number of interviews and the number of observations (each observation is the strategy used per month and boat) with information about the different strategies are indicated.

\begin{tabular}{|c|c|c|c|c|}
\hline $\begin{array}{l}\text { Gear and } \\
\text { strategy }\end{array}$ & $\begin{array}{c}\text { No } \\
\text { interviews }\end{array}$ & $\begin{array}{c}\text { No } \\
\text { observations }\end{array}$ & Target species & Accessory species \\
\hline BE & 22 & 91 & & \\
\hline Be_1 & 6 & 17 & Scomber scombrus (40\%) & M. merluccius (24\%), T. trachurus (20\%), T. luscus (13\%) \\
\hline Be_2 & 12 & 58 & Trisopterus luscus (52\%) & M. merluccius $(45 \%)$ \\
\hline $\mathrm{Be}_{-}^{-} 3$ & 5 & 16 & Merluccius merluccius (59\%) & T. luscus (21\%), Cancer pagurus (10\%), \\
\hline BO & 6 & 22 & & \\
\hline Bo_1 & 2 & 9 & Sepia officinalis $(51 \%)$ & L. vulgaris $(32 \%)$, M. surmuletus $(17 \%)$ \\
\hline Bo_2 & 4 & 13 & Loligo vulgaris $(100 \%)$ & \\
\hline $\mathbf{C E}$ & 7 & 72 & & \\
\hline Ce_1 & 6 & 35 & Sardina pilchardus $(49 \%)$ & T. trachurus $(41 \%)$ \\
\hline $\mathrm{Ce}_{-} 2$ & 5 & 18 & Trachurus trachurus $(86 \%)$ & S. pilchardus $(6 \%)$ \\
\hline $\mathrm{Ce} \_3$ & 5 & 19 & Scomber scombrus $(46 \%)$ & S. pilchardus $(29 \%)$, T. trachurus $(13 \%)$ \\
\hline $\mathbf{E N}$ & 3 & 10 & & \\
\hline En_1 & 3 & 10 & Venerupis rhomboides (100\%) & \\
\hline MĪ & 21 & 141 & & \\
\hline Mi_1 & 3 & 12 & M. merluccius $(59 \%)$ & Soleidae (12\%), Psetta maxima $(9 \%)$ \\
\hline $\mathrm{Mi}^{-} 2$ & 3 & 13 & Maja brachydactyla $(30 \%)$ & M. merluccius $(24 \%)$, L. bergylta $(15 \%)$ \\
\hline Mi_3 & 6 & 23 & Soleidae $(53 \%)$ & M. brachydactyla (23\%), Dicentrarchus labrax (13\%) \\
\hline Mi_4 & 11 & 31 & M. brachydactyla $(68 \%)$ & Soleidae $(13 \%)$ \\
\hline Mi_5 & 11 & 45 & Labrus bergylta $(72 \%)$ & M. brachydactyla $(7 \%)$ \\
\hline Mi_6 & 4 & 13 & Raja spp. (30\%) & Lophius spp. (16\%), M. brachydactyla $(13 \%)$ \\
\hline Mi_7 & 2 & 4 & S. officinalis $(72 \%)$ & M. brachydactyla $(21 \%)$ \\
\hline $\mathrm{NC}$ & 1 & 12 & & \\
\hline Nc_1 & 1 & 12 & Palaemon serratus (100\%) & \\
\hline NF & 1 & 8 & & \\
\hline Nf_1 & 1 & 8 & T. luscus $(100 \%)$ & \\
\hline $\mathbf{N N}$ & 23 & 121 & & \\
\hline Nn_1 & 23 & 121 & Necora puber $(100 \%)$ & \\
\hline $\mathbf{N P}$ & 27 & 158 & & \\
\hline Np_1 & 27 & 158 & Octopus vulgaris $(100 \%)$ & \\
\hline NV & 8 & 85 & & \\
\hline Nv_1 & 8 & 85 & Ensis arcuatus (100\%) & \\
\hline $\mathbf{O U}$ & 4 & 25 & & \\
\hline Ou_1 & 4 & 25 & Paracentrotus lividus (100\%) & \\
\hline $\mathbf{P A}$ & 6 & 38 & & \\
\hline Pa_1 & 1 & 12 & T. luscus $(84 \%)$ & C. conger $(8 \%)$ \\
\hline Pa_2 & 4 & 20 & Conger conger $(97 \%)$ & T. luscus $(3 \%)$ \\
\hline $\mathrm{Pa}_{3} 3$ & 1 & 6 & Diplodus sargus (51\%) & D. labrax $(49 \%)$ \\
\hline $\mathbf{P E}$ & 10 & 108 & & \\
\hline Pe_1 & 10 & 108 & Pollicipes pollicipes (100\%) & \\
\hline $\mathbf{R B}$ & 18 & 119 & & \\
\hline $\mathrm{Rb} \_1$ & 5 & 17 & Venerupis pullastra $(100 \%)$ & \\
\hline $\mathrm{Rb} \_2$ & 8 & 45 & V. rhomboides $(95 \%)$ & V. pullastra $(6 \%)$ \\
\hline $\mathrm{Rb} \_3$ & 10 & 57 & $V$. rhomboides $(62 \%)$ & $V$. pullastra $(38 \%)$ \\
\hline TR & 11 & 53 & & \\
\hline $\mathrm{Tr} \_1$ & 7 & 23 & S. officinalis $(75 \%)$ & M. brachydactyla $(15 \%)$, Soleidae $(8 \%)$ \\
\hline Tr_2 & 3 & 17 & L. bergylta $(74 \%)$ & M. brachydactyla $(11 \%)$, S. officinalis $(7 \%)$ \\
\hline $\mathrm{Tr}_{2} 3$ & 3 & 13 & M. brachydactyla $(34 \%)$ & D. sargus $(28 \%)$, L. bergylta $(25 \%)$ \\
\hline $\mathbf{X E}$ & 6 & 23 & & \\
\hline $\mathrm{Xe} \_1$ & 6 & 23 & S. pilchardus $(99 \%)$ & \\
\hline
\end{tabular}

in the archipelago by purse seiners and polyvalent vessels equipped with powerful engines for long journeys.

According to the surveys $(n=424), 78.1 \%$ of artisanal and polyvalent fleet is allowed to use 4 or 5 gears, although only $6.2 \%$ use all authorized gears. Of the vessels fishing in the Cíes Islands, $64.8 \%$ fish with two or three gears and half fish with only one gear. On average, each boat has a fishing licence to use 4.14 $( \pm 0.05 \mathrm{SE})$ different gears, but they only use $2.22 \pm 0.05$ routinely, and they only fish in the Cíes Islands with $0.91 \pm 0.05$ of them.

We identified 19 gears operating in the Cíes Islands (Table 1), which include both passive gears (longlines, traps, gillnets and entangling nets) and active gears (hand harvesting of benthic resources, artisanal trawls, seines and rakes). Because some fishing gears used in Galicia do not have a specific name in English, we have defined them according to their characteristics
(Table 1). For example, both Miños and Trasmallos are trammel nets but differ in the panel mesh size combinations. For this reason we defined Miños as Largemesh trammel net (minimum mesh sizes are 500 and $90 \mathrm{~mm}$ for external and internal panels, respectively), and Trasmallos as Small-mesh trammel net (400 and $70 \mathrm{~mm}$ for external and internal panels). We will use these English terms to refer to the gears.

The fishing gears most commonly used in the Cíes Islands are manual clam rakes (RB in Table 1, used by $17.5 \%$ of the fleet in the Cíes Islands), pots targeting common octopus (NP: 13.4\%) and velvet crab (NN: $11.5 \%)$, large-mesh trammel nets (MI: 11.4\%), and set gillnets (BE: $8.7 \%$ ). Although the number of licences for $\mathrm{S}$-fisheries is low (except for manual clam rakes since the TURF is shared among all fishers' associations located in the Ría de Vigo), the Cíes Islands are an important fishing area for these fisheries. Thus, by 
estimating the ratio of the fleet fishing in the Cíes Islands related to the number of boats with a licence to use a given gear in Galicia, we found that the fisheries with the greatest representation of their fleet in the Cíes Islands are gooseneck barnacle (PE: $100 \%$ ), razor clam (NV: $100 \%$ ), purse seine (CE: $72 \%$ ), and sea urchin fisheries (OU: $71.4 \%$ ), while only $26.7 \%$ and $20.5 \%$ of the pot fleet targeting octopus and velvet crabs, respectively, operated in the Cíes Islands.

From the information obtained in the interviews $(n=96)$, we analysed the catch profile of the gears. Except for drifting gillnets, we identified more than one possible catch profile for each multi-species gear, which indicates the existence of different fishing strategies (Fig. 2). For example, purse seiners have three different target species (mackerel, horse mackerel and sardine) depending on the fishing strategy used, and in the case of large-mesh trammel nets the number of strategies is up to seven (Table 2).

At least 33 fishing strategies are used in the Cíes Islands (the multi-species gears BM, LI and RA have not been analysed because of the lack of data). The strategies used by the largest number of boats are Np_1 (pots targeting octopus), Nn_1 (pots targeting velvet crab), Be_2 (set gillnets targeting pouting and hake), Mi_4 (large-mesh trammel nets targeting European spider crab) and Mi_5 (large-mesh trammel nets targeting ballan wrasse), although some of them are employed for very short periods of time. For this reason, the results are different when we analyse the number of observations during the interviews (strategy employed per boat and month), in which case the most important strategies were $\mathrm{Np} \_1, \mathrm{Nn} \_1, \mathrm{Pe} \_1, \mathrm{Nv} \_1, \mathrm{Be} \_2$ and Rb_3 (Fig. 3).

\section{The fleet dynamics}

Artisanal and polyvalent boats use between 1 and $7(2.2 \pm 0.1)$ fishing strategies per vessel throughout the year, with many possible combinations of strategies. Despite the wide variety of resulting fishing patterns, we identified 12 groups of vessels with similar annual activity by means of a multivariate analysis (Fig. 4). Four of these groups are made up of specialist vessels that harvest gooseneck barnacle (group 1), razor clam (group 2), octopus with pots (group 3) or clams with manual rakes (group 7) on around $75 \%$ and $100 \%$ of their fishing days. The remaining groups are made up of generalist vessels that modify their target species throughout the year, although a tendency to combine fishing strategies belonging to the same gear or similar gears can be observed. Thus, vessels included in the group 8 alternate two strategies carried out with clam rakes ( $R b \_1$ and $\left.R b \_2\right)$, group 9 is characterized by the combination of different strategies carrid out with large-mesh trammel nets (Mi_5, Mi_2 and Mi_3), and the vessels included in group 6 use mainly pots targeting crab $\left(\mathrm{Nn} \_1\right)$ but they often alternate with pots targeting octopus (Np_1) and shrimp (Nc_1).

The fishing dynamics of the generalist vessels can be better understood if the combinations of strategies

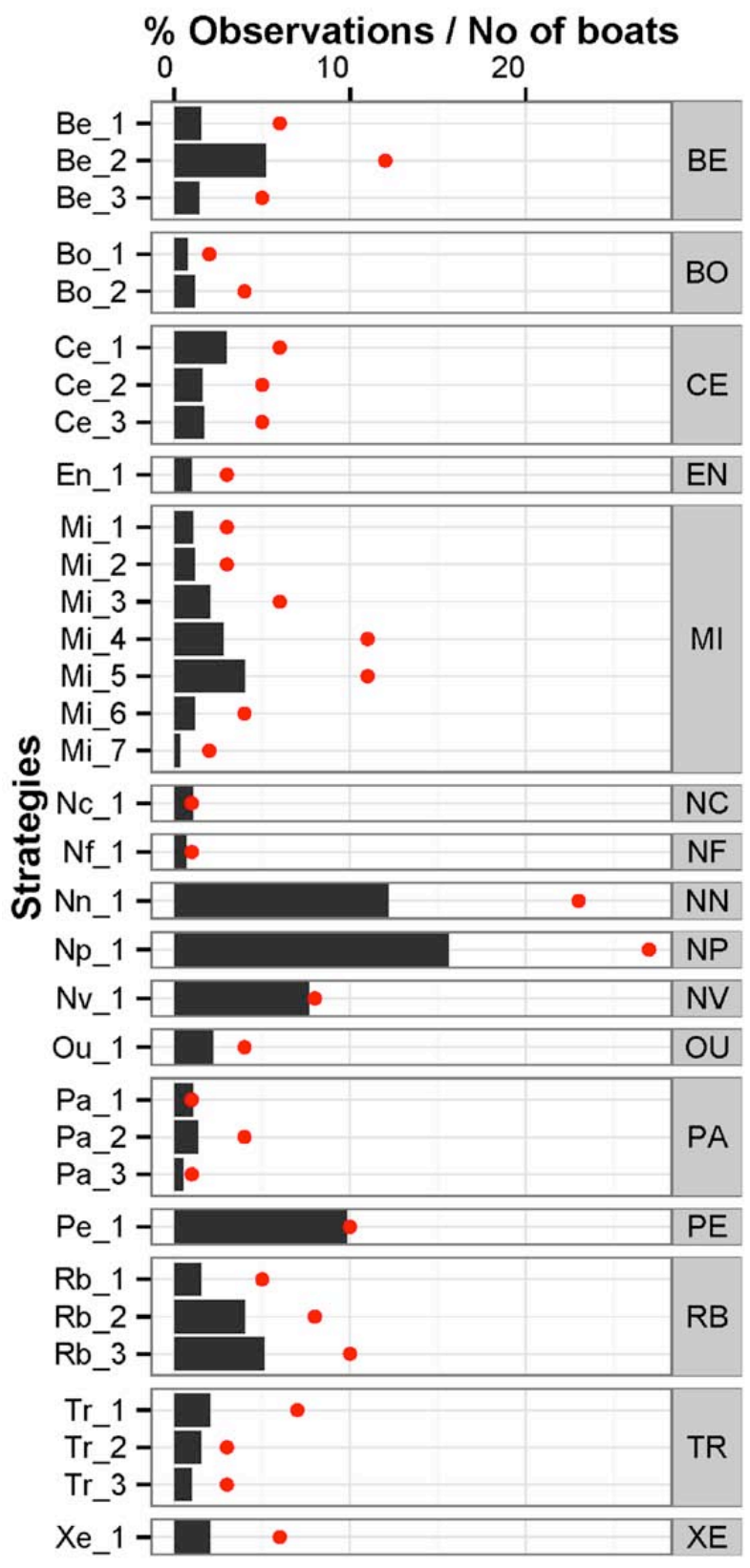

Fig. 3. - Use of the fishing strategies in the Cíes Islands (see Table 2 for the explanation of each strategy). Bars show the percentage of observations (strategy used per interviewed boat and month) belonging to each strategy. Dots show the number of interviewed boats that used a given strategy sometime in the year.

and their temporal use are analysed together. Figure 5 shows that some strategies have a strong seasonal pattern, so the vessels have to combine them with other strategies in order to complete the fishing year. This is the case of small-mesh trawls (Bo_1, Bo_2) and drifting gillnets (Xe_1), used almost exclusively during the summer; mechanized clam rakes (En_1), used in the summer and Christmas season; and the sea urchin fishery $(\mathrm{Ou}$ _1), which takes place between October and April. Large-mesh trammel nets (Mi_1, ..., Mi_7) are present throughout the year in the Cíes Islands, but their use is more prevalent during the winter. Conversely, pots targeting velvet crab (Nn_1) become im- 


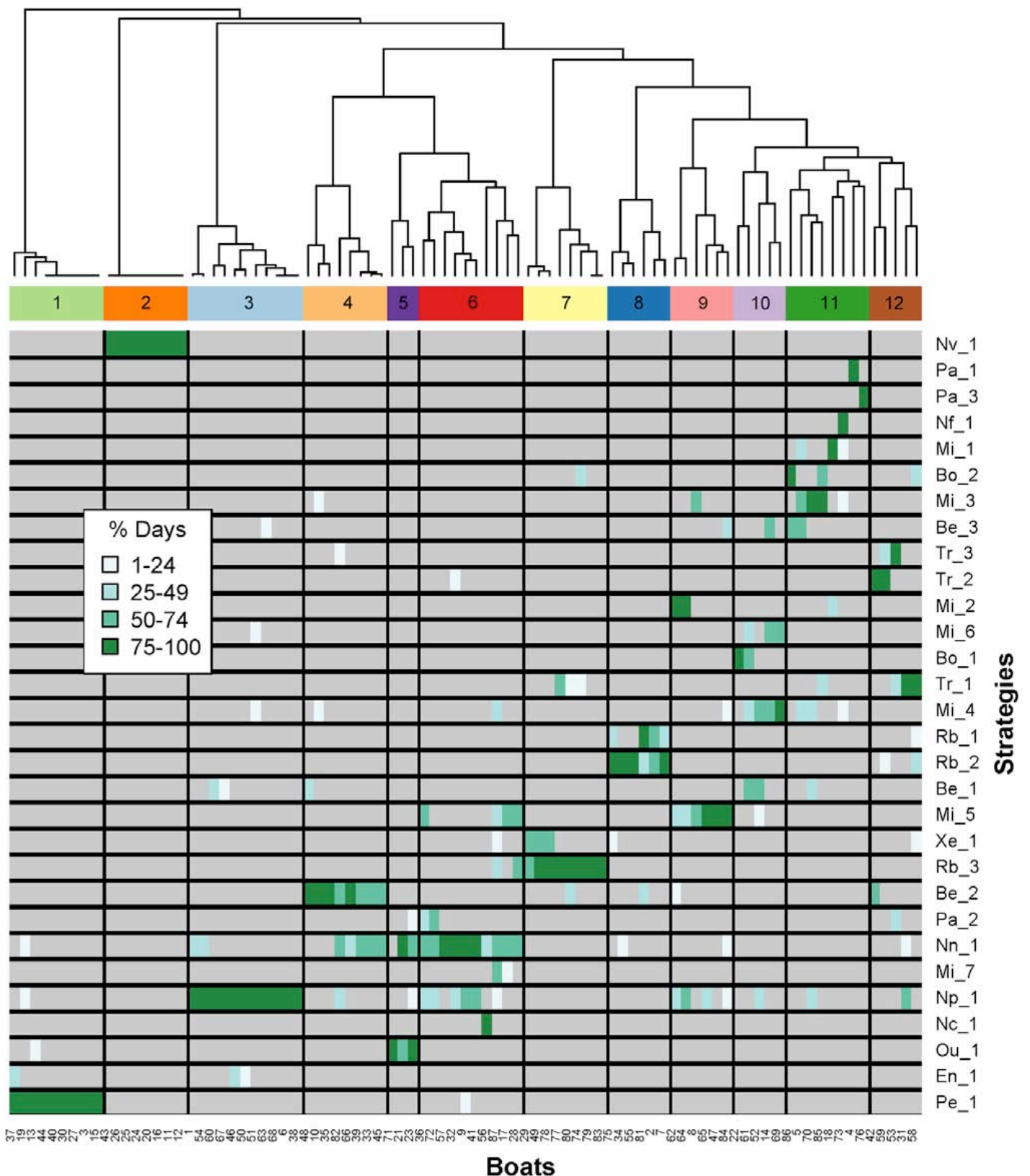

Fig. 4. - Heat map showing the combination of the fishing strategies most frequently combined by the interviewed boats (X-axis). The dendrogram and colourbar on the top show the 12 types of fleet identified by the cluster analysis according to their annual fishing pattern. The green colour gradient shows the importance of the different fishing strategies for each boat in terms of percentage of days using the fishing strategies.

portant from July to December. This seasonality partly reflects the combinations of strategies most frequently carried out by the fleet. Thus, the fleet devoted to Nn_1 changes its fishing strategy during the first six months of the year, resulting in an increase in the number of boats using large-mesh trammel nets and pots targeting octopus (group 6 in Fig. 4), boats harvesting sea urchin (group 5) or boats using set gillnets (group 4). As expected, strategies used by specialist vessels (Pe_1, $\mathrm{Nv} \_1, \mathrm{~Np} \_1, \mathrm{Rb} \_3$ ) are employed all year.

\section{Fishing effort}

The fishing capacity, in terms of engine power, number of crew and length of vessels, increases from artisanal to polyvalent up to the purse seine vessels (See Table 2 in Cambiè et al. 2012). However, the artisanal segment of the fleet is the largest in terms of the number of boats and fishers, and therefore the fishing effort $\left(\mathrm{FE}_{1}\right)$ in the Cíes Islands is mainly from this sector, with an average of $189827( \pm 24140)$ GT $\cdot$ days, followed by purse seiners $(85653 \pm 15197$ GT . days) and polyvalent $(29541 \pm 5849 \mathrm{GT} \cdot$ days $)$.

The differences observed in the fishing effort between strategies were caused by variations in both the number of fishing days and the size of the gears (Fig. 6). Mi_1 exerts the greatest fishing pressure within the net gears, with each boat using a daily average of $15 \mathrm{~km}$ of net and fishing 160 days in the Cíes Islands. Removing this atypical data obtained from one vessel, 


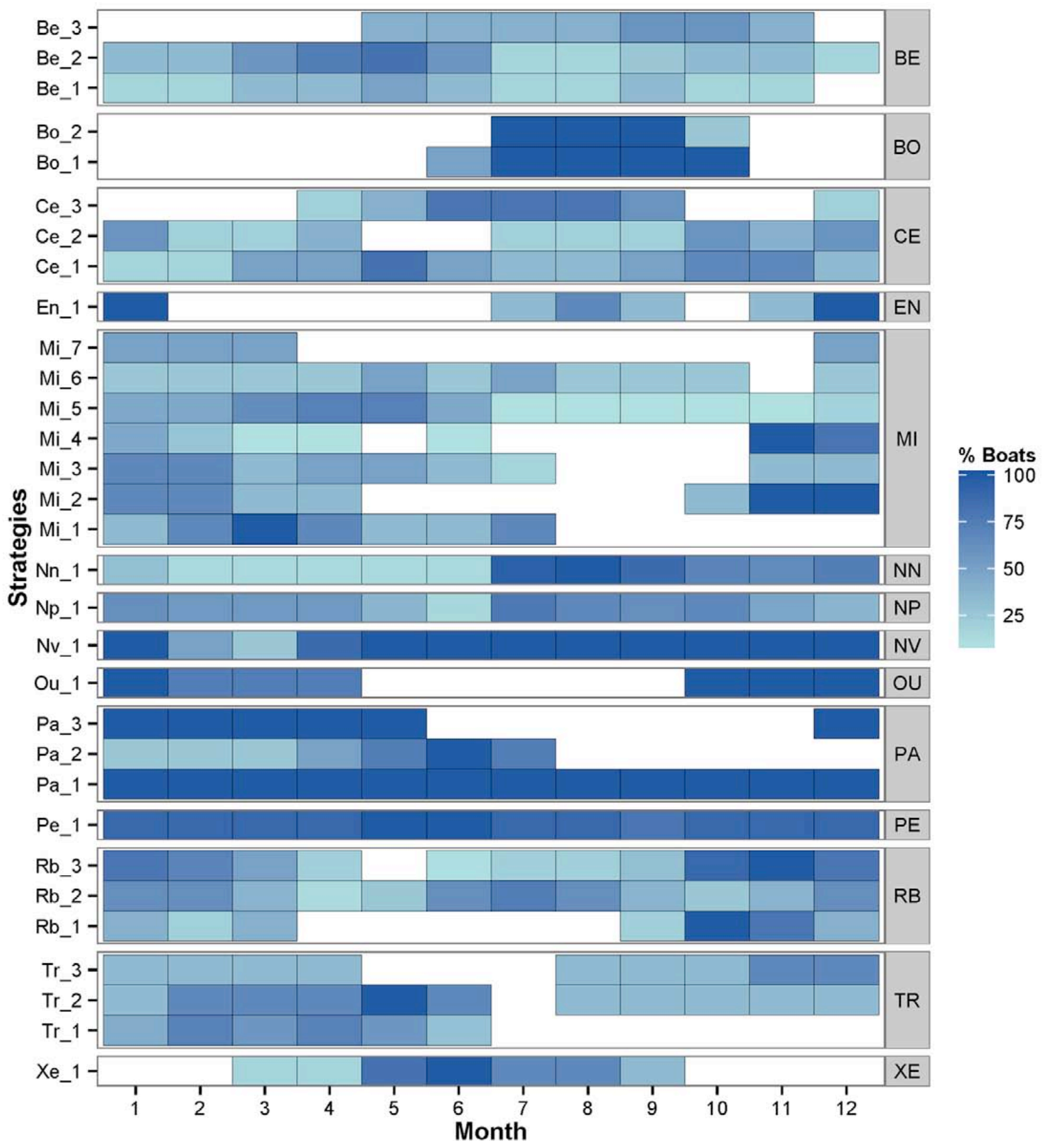

Fig. 5. - Seasonal variation in the use of the fishing strategies. The gradient colour shows the proportion of boats using a particular strategy per month related to the total of boats using that strategy.

the differences between strategies are still significant (one-way ANOVA, F=2.69, $\mathrm{p}<0.01$ ), the fishing effort being lowest with $\mathrm{Xe} \_1, \mathrm{Tr} \_1$ and $\mathrm{Mi}$ 3 3 because of a lower fishing capacity $(\mathrm{F}=5 . \overline{2} 1, \mathrm{p}<0.01)$. Whereas boats launch an average of $31972 \pm 7331$ octopus pots per year in the Cíes Islands (Np_1), the number of pots targeting velvet crab $\left(\mathrm{Nn} \_1\right)$ is lower $(8690 \pm 2135$ pot $\left.\cdot \mathrm{yr}^{-1}, \mathrm{~F}=4.85, \mathrm{p}=0.01\right)$ because of the fishery's closure between January and July. The fishing effort applied by pots targeting shrimps (Nc_1) is negligible within the study area.

Regarding the S-fisheries, the fishing effort exerted on gooseneck barnacles (Pe_1) and razor clams $\left(\mathrm{Nv} \_1\right)$ was higher $(\mathrm{F}=7.56, \mathrm{p}<0.01)$ because of the large number of fishing days in the Cíes Islands: $90 \pm 15$ and $138 \pm 23$ days, respectively. We did not find significant differences between the fishing strategies carried out with hooks $(\mathrm{F}=8.17, \mathrm{p}=0.11)$ or trawls $(\mathrm{F}=2.38$, $\mathrm{p}=0.26$ ), but some of these data (specifically data of Pa_1 and Bo_1) should be interpreted with caution because they were estimated from a single interview.

\section{DISCUSSION}

Through the dialogue with fishers, we identified the fleet in an area of special ecological interest in Galicia, the fishing dynamics and the effort associated with each fishing strategy. This information is essential for im- 

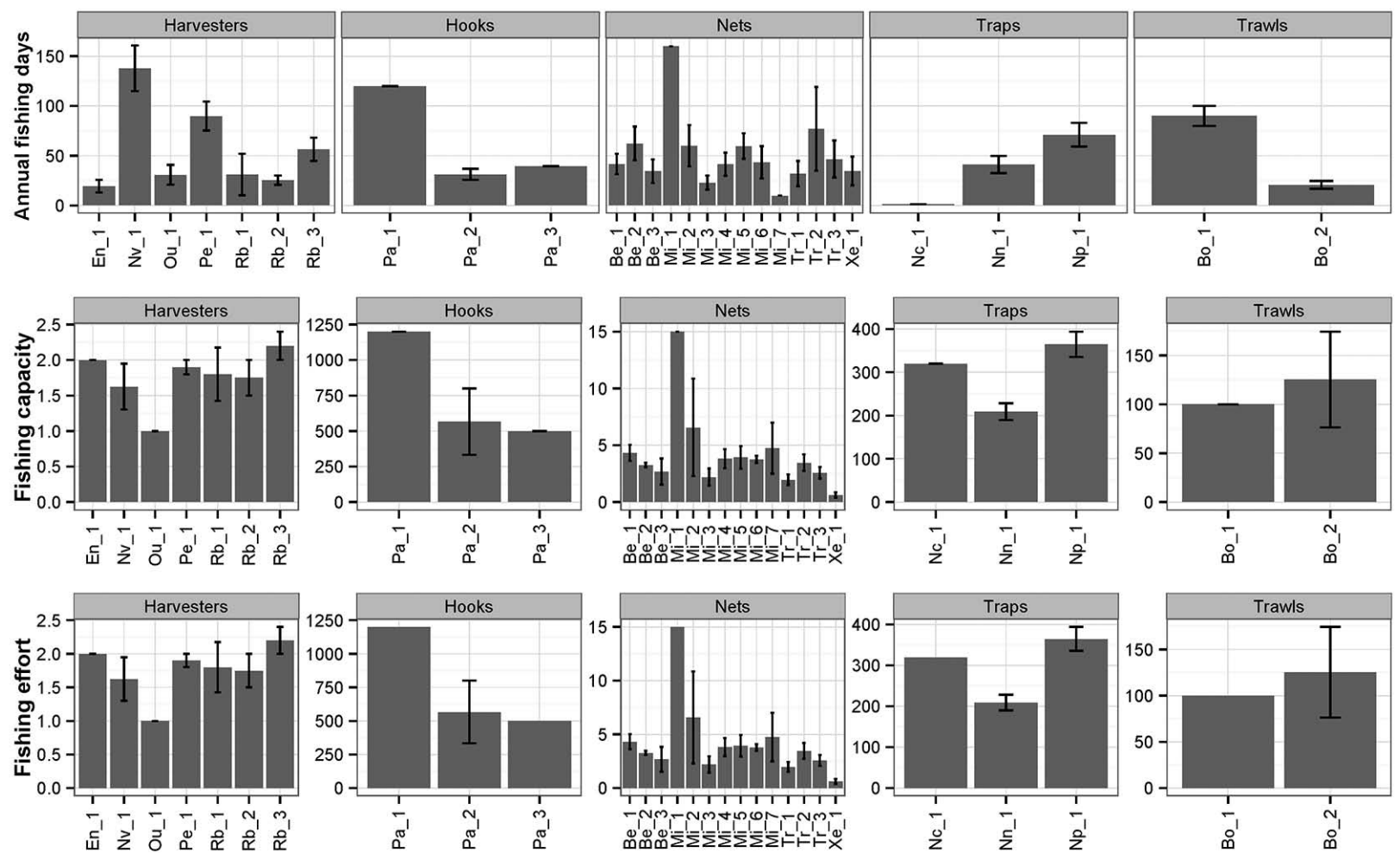

Fig. 6. - Mean $( \pm \mathrm{SE})$ of the number of annual fishing days, fishing capacity, and the annual fishing effort (FE $\left.\mathrm{F}_{2}\right)$ exerted by an artisanal boat in the Cíes Islands using the different fishing strategies. Fishing capacity was measured as number of harvesters (for S-fisheries), number of hooks (for longlines), length of net in $\mathrm{km}$ (for gillnets and trammel nets), number of pots (for trap gears), and length of the wing net in $\mathrm{m}$ (for trawl gears). $\mathrm{FE}_{2}$ was estimated as the product of fishing days and fishing capacity.

plementing the EAF, because it reveals how the fishing effort is allocated in space and time, its impact on the resources, and how the fleet will respond to a change in the ecosystem or a new management regulation.

Our results highlight the complexity of the fishery system in Galicia, dominated by artisanal vessels that can use up to five different gears. Since the fishing licence is transferable with the boat, fishers aspire to include many gears in their fishing permit to increase the value of the boat, although they do not actually intend to fish with them. In fact, artisanal fishers estimate that their fishing licence represents almost $40 \%$ of the value of the boat, and the value is even higher if the gears belong to the group of S-fisheries (Cambiè et al. 2012).

Although some of the gears used by the artisanal and polyvalent fleet in Galicia are highly selective (e.g. pots and manual collection techniques), the catch composition varies greatly in most of the cases depending on the fishing area, season and mesh size. The combination of these factors generates a diversity of fishing strategies targeting different species that add complexity to the fishery system.

Despite the socio-economic importance of the fisheries in Galicia, to our knowledge this is the first study analysing the fishing strategies in this region. In fact, the articles identifying fishing strategies in Spain were performed in the Mediterranean and/or southern areas of the country (Silva et al. 2002, Forcada et al. 2010, Maynou et al. 2011, Martín et al. 2012), where the fishing activity is different and less complex to that identified in this study. Studies carried out in other regions identified between 7 and 17 strategies (Forcada et al. 2010, Maynou et al. 2011), whereas we have described 33 different fishing techniques operating in an area of $26.6 \mathrm{~km}^{2}$. The target species were also different: whereas most of the target species for Mediterranean small-scale fleet are finfish such as striped red mullet, common sole, gilthead seabream, common pandora and Atlantic bonito (Martín et al. 2012), many of the main fisheries in Galicia target benthic invertebrates of high commercial value, such as common octopus, velvet crab, European spider crab, clams and gooseneck barnacles.

This wide variety of fishing strategies, with noteworthy differences in catch composition and temporal distribution, suggests that the actual effort invested in the resources cannot be only estimated per gear. If it were, an increase in the number of vessels using largemesh trammel net, for example, would be interpreted as an increase in the fishing mortality of European spider crab (target species in terms of catch weights at gear level), whereas in fact the harmed species depends on the fishing strategy in which the increased effort takes place. Consequently, spatial and temporal data of fishing effort at strategy level are fundamental to understand the impact on resources and ecosystems, and to establish suitable management regulations accordingly.

The fact that most of the fleets are generalist using several strategies throughout the year adds a higher level of complexity in the fisheries' functioning. The choice of fishing strategy depends on a host of variables whose ultimate goal is to increase the economic perfor- 
mance. The local knowledge on the spatial-temporal migration dynamics of target species, the temporal variations in recent catches, the weather, the personal preferences of the skipper, the fish prices, the fishing regulations, and the gears they are allowed to use from their licence are some of the influential aspects in the selection of fishing strategy, and ultimately in the temporal pattern of the fishing activities (Andersen et al. 2012). Thus, we have observed that strategies targeting sardine ( $\mathrm{Ce} 1$ and $\mathrm{Xe} 1$ ) are mainly used in late spring and early summer, when the sardines approach the coast (Villasante 2010). Similarly, Mi 2, Tr 3 and Mi 4, targeting spider crab, are particularly important in November and December, when the closed season for this species ends and the price market is high.

Understanding these fishing patterns and their distribution in space is essential to reduce the uncertainty associated with fishers' behaviour and carry out effective management actions within the EAF. For example, the EU is currently considering banning drift gillnets. How would this measure affect the ecosystem? Which fleet would be harmed with this measure? Which one would be benefited? These questions can only be answered by knowing the ecosystem functioning and the fleet dynamics. Specifically this legislative change, whose aim is to increase the biomass of sardine, would not produce great achievements in our study area since sardine catches from drift gillnets are very small compared with those from purse seines (unpublished data). However, assuming that the biomass of sardine will increase, a greater abundance of predators such as hake should be also expected, so the fleet of large-mesh trammel nets and set gillnets could be benefited. On the other hand, the fleet of drift gillnets would begin to fish other resources. According to the fishing patterns identified in this study, the prohibition of this gear would be associated with an increase in the fishing effort by manual clam rakes (group 7 in Fig. 4).

Regarding fishing effort, this study concludes that 565 vessels, most of them artisanal, fished in the Cíes Islands in 2008. This number is high when compared with that in other regions with similar ecological interest. Between 9 and 13 artisanal vessels fish in an area of $12.2 \mathrm{~km}^{2}$ within the French National Park of Port Cross (Cadiou et al. 2009), and 51 vessels fish in the Tabarca Marine Reserve $\left(14 \mathrm{~km}^{2}\right)$ in Spain (Forcada et al. 2010). In both cases there is a census of vessels authorized to fish within the protected areas and some particular fishing regulations are in place. Similar measures should be taken in the Cíes Islands to control the effort within the park and to reduce it if necessary.

Many fishing regulations of the Galician fisheries are based on restricting the fishing effort through the dimensions of the gears, but these regulations are difficult to enforce. Comparing the size of the gears used in the Cíes Islands with the maximum capacity allowed by law at that time, we found that $35 \%$ of the vessels did not respect the rules. This percentage is probably even higher since some fishers might have hidden the truth during the interview. According to information provided by the fishers, the legal dimensions of the gears were exceeded by 200 hooks (information from one vessel), $154.5 \pm 25.6$ pots (15 vessels), $2.3 \pm 0.6 \mathrm{~km}$ of net (20 vessels) and $57.7 \pm 32.4 \mathrm{~m}$ of length of the wing net ( 3 vessels). The problem is not only that the enforcement mechanisms are not sufficient, but also that the management system is not adapted to the changing and complex reality that fishers must face, and consequently they break the rules. A higher participation of fishers in the management system, as well as the development and implementation of data collection programmes that include fleet dynamics and spatial information, are key factors to create an adaptive governance system and carry out a management consistent with the complexity of the fisheries.

\section{ACKNOWLEDGEMENTS}

We gratefully acknowledge financial support from the Spanish Ministry of the Environment, the European Regional Development Fund and the Spanish Juana de Vega Foundation. We would like to thank the National Marine Park of the Atlantic Islands of Galicia and the "Consellería do Mar" of the Autonomous Government of Galicia ("Xunta de Galicia") for their cooperation. Special thanks to the fishing cooperative "Cofradía de Cangas" and all the fishers involved for the valuable information they provided. Finally, we thank two anonymous reviewers for their helpful comments and suggestions.

\section{REFERENCES}

Álvarez-Salgado X., Gago J., Míguez B.M., et al. 2000. Surface waters of the NW Iberian margin: Upwelling on the shelf versus outwelling of upwelled waters from the Rías Baixas. Estuar. Coast Shelf Sci. 51: 821-837. http://dx.doi.org/10.1006/ecss.2000.0714

Andersen B.S., Ulrich C., Eigaard O.R., et al. 2012. Short-term choice behaviour in a mixed fishery: investigating metier selection in the Danish gillnet fishery. ICES J. Mar. Sci. 69: 131-143. http://dx.doi.org/10.1093/icesjms/fsr181

Booth A.J. 2000. Incorporating the spatial component of fisheries data into stock assessment models. ICES J. Mar. Sci. 57: $858-865$.

http://dx.doi.org/10.1006/jmsc.2000.0816

Cadiou G., Boudouresque C.F., Bonhomme P., et al. 2009. The management of artisanal fishing within the Marine Protected Area of the Port-Cros National Park (northwest Mediterranean Sea): a success story? ICES J. Mar. Sci. 66: 41-49. http://dx.doi.org/10.1093/icesjms/fsn188

Cambiè G., Ouréns R., Fernández-Vidal D., et al. 2012. Economic performance of coastal fisheries in Galicia (NW Spain): case study of the Cíes Islands. Aquat. Living Resour. 25: 195-204. http://dx.doi.org/10.1051/alr/2012010

Costello C., Ovando D., Hilborn R., et al. 2012. Status and solutions for the world's unassessed fisheries. Science 338: 517-520. http://dx.doi.org/10.1126/science.1223389

Crowder L., Norse E. 2008. Essential ecological insights for marine ecosystem-based management and marine spatial planning. Mar. Policy 32: 772-778. http://dx.doi.org/10.1016/j.marpol.2008.03.012

De Young C., Charles A., Hjort A. 2008. Human dimensions of the ecosystem approach to fisheries: an overview of context, concepts, tools and methods. FAO Fish. Tech. Pap. 489

FAO. 1999. Guidelines for the routine collection of capture fishery data. Prepared at the FAO/DANIDA Expert Counsultation, Bangkok, Thailand, 18-30 May 1998. Rome.

FAO. 2003. Fisheries management. 2. The ecosystem approach to fisheries. Rome.

FAO. 2014. The state of world fisheries and aquaculture. Opportunities and challenges. Rome.

Folke C., Pritchard L., Berkes F., et al. 2007. The problem of fit 
between ecosystems and institutions: Ten years later. Ecol. Soc. 12: 30 .

Forcada A., Valle C., Sanchez-Lizaso J.L., et al. 2010. Structure and spatio-temporal dynamics of artisanal fisheries around a Mediterranean marine protected area. ICES J. Mar. Sci. 67: 191-203. http://dx.doi.org/10.1093/icesjms/fsp234

Fulton E.A., Smith A.D.M., Smith D.C., et al. 2011. Human behaviour: The key source of uncertainty in fisheries management. Fish Fish. 12: 2-17. http://dx.doi.org/10.1111/j.1467-2979.2010.00371.x

Jennings S., Rice J. 2011. Towards an ecosystem approach to fisheries in Europe: a perspective on existing progress and future directions. Fish Fish. 12: 125-137. http://dx.doi.org/10.1111/j.1467-2979.2011.00409.x

Leslie H.M., McLeod K.L. 2011. Confronting marine the challenges of implementing marine ecosystem-based management. Front Ecol. Environ. 5: 540-548. http://dx.doi.org/10.1890/060093

Levin P.S., Fogarty M.J., Murawski S.A., et al. 2009. Integrated ecosystem assessments: developing the scientific basis for ecosystem-based management of the ocean. PLoS Biol. 7(1): e1000014. http://dx.doi.org/10.1371/journal.pbio.1000014

Losada A. 2000. La política del mar. Políticas públicas y autonomía. El caso de la pesca gallega. Istmo.

Macho G., Naya I., Freire J., et al. 2013. The key role of the Barefoot Fisheries Advisors in the co-managed TURF system of Galicia (NW Spain). Ambio. 42: 1057-1069. http://dx.doi.org/10.1007/s13280-013-0460-0

Maravelias C.D., Haralabous J., Tsitsika E.V. 2014. Fishing strategies and the Ecosystem Approach to Fisheries in the eastern Mediterranean Sea. Sci. Mar. 78S1: 77-85. http://dx.doi.org/10.3989/scimar.04026.24A

Martín P., Maynou F., Stelzenmüller V., et al. 2012. A small-scale fishery near a rocky littoral marine reserve in the northwestern Mediterranean (Medes Islands) after two decades of fishing prohibition. Sci. Mar. 76: 607-618. http://dx.doi.org/10.3989/scimar.03471.07F

Martín P., Muntadas A., de Juan S., et al. 2014. Performance of a northwestern Mediterranean bottom trawl fleet: How the integration of landings and VMS data can contribute to the implementation of ecosystem-based fisheries management. Mar. Policy 43: 112-121. http://dx.doi.org/10.1016/j.marpol.2013.05.009

Maynou F., Recasens L., Lombarte A. 2011. Fishing tactics dynamics of a Mediterranean small-scale coastal fishery. Aquat. Living Resour. 24: 149-159 http://dx.doi.org/10.1051/alr/2011131

McCluskey S.M., Lewison R.L. 2008. Quantifying fishing effort: a synthesis of current methods and their applications. Fish Fish. 9: $188-200$. http://dx.doi.org/10.1111/j.1467-2979.2008.00283.x

Molares J., Freire J. 2003. Development and perspectives for community-based management of the goose barnacle (Pollicipes pollicipes) fisheries in Galicia (NW Spain). Fish. Res. 65: 485-492.

http://dx.doi.org/10.1016/j.fishres.2003.09.034
Orensanz J., Jamieson G.S. 1998. The assesment and management of spatially structured stocks: an overview of the North Pacific Symposium on invertebrate stock assessment and management. In: Jamieson G., Campbell A. (eds) Proc. North Pacific Symp. Invertebr. Stock Assess. Manag. Can. Spec. Publ. Fish. Aquat. Sci, 125: 441-459.

Orensanz J., Parma A.M., Jerez G., et al. 2005. What are the key elements for the sustainability of "S-Fisheries"? Insights from South America. Bull. Mar. Sci. 76: 527-556.

Ouréns R., Naya I., Freire J. 2015. Mismatch between biological, exploitation, and governance scales and ineffective management of sea urchin (Paracentrotus lividus) fisheries in Galicia. Mar. Policy 51: 13-20. http://dx.doi.org/10.1016/j.marpol.2014.07.015

Pascoe S., Kirkley J., Gréboval D., et al. 2003. Measuring and assessing capacity in fisheries. 2. Issues and methods. Rome.

Pelletier D., Ferraris J. 2000. A multivariate approach for defining fishing tactics from commercial catch and effort data. Can. J. Fish. Aquat. Sci. 57: 51-65. http://dx.doi.org/10.1139/cjfas-57-1-51

Pita P., Freire J., García-Allut A. 2008. How to assign a catch value to fishing grounds when fisheries statistics are not spatially explicit. Sci. Mar. 72: 693-699. http://dx.doi.org/10.3989/scimar.2008.72n4693

R Core Team. 2014. R: A language and environment for statistical computing. R Foundation for Statistical computing. Viena, Austria.

Rodil I.F., Lastra M., López J. 2009. Spatial variability of benthic macrofauna in the Ría of Vigo (NW Spain): Effect of sediment type and food availability. Mar. Biol. Res. 5: 572-584. http://dx.doi.org/10.1080/17451000902729688

Salas S., Gaertner D. 2004. The behavioural dynamics of fishers: management implications. Fish Fish. 5: 153-167. http://dx.doi.org/10.1111/j.1467-2979.2004.00146.x

Silva L., Gil J., Sobrino I. 2002. Definition of fleet components in the Spanish artisanal fishery of te Gulf of Cádiz (SW Spain ICES division IXa). Fish. Res. 59: 117-128. http://dx.doi.org/10.1016/S0165-7836(01)00420-9

Tzanatos E., Somarakis S., Tserpes G., et al. 2006. Identifying and classifying small-scale fisheries métiers in the Mediterranean: A case study in the Patraikos Gulf, Greece. Fish. Res. 81: $158-168$. http://dx.doi.org/10.1016/j.fishres.2006.07.007

Ulrich C., Andersen B.S. 2004. Dynamics of fisheries, and the flexibility of vessel activity in Denmark between 1989 and 2001. ICES J. Mar. Sci. 61: 308-322. http://dx.doi.org/10.1016/j.icesjms.2004.02.006

Varela Lafuente M., Iglesias Malvido C. 2000. Tendencias e problemas da pesca galega no contexto mundial e comunitario. Rev. Galega Econ. 9: 197-222.

Villasante S. 2010. Sostenibilidad de las pesquerías artesanales de Galicia. Biblo, Oleiros, España.

Ward J. 1963. Hierarchical grouping to optimize an objective function. J. Am. Stat. Assoc. 58: 236-244. http://dx.doi.org/10.1080/01621459.1963.10500845

World Bank 2009. The Sunken Billions: The economic justification for fisheries reform. Washington. 